\title{
Phylogenetic group determination and plasmid virulence gene profiles of colistin-resistant Escherichia coli originated from the broiler meat supply chain in Bogor, Indonesia
}

\author{
Irma Rahayuningtyas ${ }^{1,2}$ (i) Agustin Indrawati $^{1}$ (D) I Wayan Teguh Wibawan ${ }^{1}$, Maria Fatima Palupi² ${ }^{2}$ and \\ Istiyaningsih Istiyaningsih² ${ }^{2}$
}

\begin{abstract}
1. Department of Animal Disease and Veterinary Public Health, Faculty of Veterinary Medicine, IPB University-Bogor, Indonesia; 2. National Veterinary Drug Assay Laboratory, Directorate General of Livestock and Animal Health, Ministry of Agriculture of the Republic of Indonesia, Indonesia.

Corresponding author: Agustin Indrawati, e-mail: titin.seta@gmail.com

Co-authors: IR: drh.irmarahayuningtyas@gmail.com, IWTW: teguhwibawan@yahoo.co.id, MFP: lupi_ima@yahoo.co.id, II: ningsagita29@yahoo.com
\end{abstract}

Received: 13-04-2020, Accepted: 21-07-2020, Published online: 05-09-2020

doi: www.doi.org/10.14202/vetworld.2020.1807-1814 How to cite this article: Rahayuningtyas I, Indrawati $A$, Wibawan IWT, Palupi MF, Istiyaningsih I (2020) Phylogenetic group determination and plasmid virulence gene profiles of colistin-resistant Escherichia coli originated from the broiler meat supply chain in Bogor, Indonesia, Veterinary World, 13(9): 1807-1814.

\begin{abstract}
Background and Aim: Pathogenic Escherichia coli contamination along the broiler meat supply chain is a serious public health concern. This bacterial infection with multidrug-resistant can lead to treatment failure. Several studies have revealed that avian pathogenic E. coli (APEC) and human extraintestinal pathogenic E. coli (ExPEC) showed a close genetic relationship and may share virulence genes. This study aimed to determine the phylogenetic group and virulence gene profiles in colistin-resistant E. coli obtained from the broiler meat supply chain in Bogor, West Java, Indonesia.

Materials and Methods: Fifty-eight archive isolates originated from the cloacal swab, litter, drinking water, inside plucker swab, fresh meat at small scale poultry slaughterhouses, and traditional markets were used in this study. All the isolates were characterized by a polymerase chain reaction to determine the phylogenetic group (A, B1, B2, or D) and virulence gene profiles with APEC marker genes (iutA, hlyF, iss, iroN, and ompT).

Results: Phylogenetic grouping revealed that the isolates belong to A group $(34.48 \%)$, D group (34.48\%), B1 group $(17.24 \%)$, and B2 group (13.79\%). The virulence gene prevalence was as follows: iutA (36\%), hlyF $(21 \%)$, ompT $(21 \%)$, iroN $(10 \%)$, and iss $(9 \%)$. The B2 group presented with more virulence genes combinations. iroN, hlyF, and ompT genes were positively associated with the B2 group $(\mathrm{p} \leq 0.05)$.
\end{abstract}

Conclusion: Our results highlight the role of colistin-resistant E. coli originated from the broiler meat supply chain as a potential reservoir for human ExPEC virulence genes.

Keywords: broiler supply chain, Escherichia coli, phylogenetic group, virulence gene.

\section{Introduction}

Most Escherichia coli are commensal bacteria, but some strains are pathogenic in humans and warmblooded animals. One of the critical pathogenic E. coli is extraintestinal pathogenic E. coli (ExPEC). This pathotype may cause systemic infections in humans and animals. ExPEC subpathotypes include uropathogenic E. coli (UPEC), neonatal meningitis $E$. coli (NMEC), sepsis-associated E. coli (SePEC), and avian pathogenic E. coli (APEC). UPEC causes urinary tract infections (UTI), NMEC leading to neonatal meningitis, and SePEC, which causes sepsis in humans [1]. APEC is the causative agent of colibacillosis, which may cause economic losses to the worldwide poultry

Copyright: Rahayuningtyas, et al. Open Access. This article is distributed under the terms of the Creative Commons Attribution 4.0 International License (http://creativecommons.org/licenses/ by/4.0/), which permits unrestricted use, distribution, and reproduction in any medium, provided you give appropriate credit to the original author(s) and the source, provide a link to the Creative Commons license, and indicate if changes were made. The Creative Commons Public Domain Dedication waiver (http:// creativecommons.org/publicdomain/zero/1.0/) applies to the data made available in this article, unless otherwise stated. industry [2]. Colibacillosis signs are airsacculitis, polyserositis, coligranuloma, cellulitis, omphalitis, swollen head syndrome, and systemic infections [3].

Several studies reported that there are genetic similarities between ExPEC in chickens and humans, especially in virulence genes $[4,5]$. Plasmids that carry virulence genes in APEC can be a source of virulence genes for commensal E. coli strains or other human ExPEC [6,7]. This statement is consistent with the hypothesis that poultry products can act as reservoirs of potentially zoonotic pathogenic bacteria [8]. Conversely, several studies have proven that isolates that cause ExPEC in humans may cause colibacillosis in chicken and laboratory animals $[9,10]$. The problem increases when virulence genes and antibiotic resistance genes can be transferred to other bacteria, both commensal and pathogenic [6-8]. This problem causes the need for research on the potency of colistin-resistant $E$. coli originated from the broiler meat supply chain as a reservoir of colistin-resistance genes and ExPEC virulence genes in humans. 
This study was conducted to determine the phylogenetic group and virulence gene profiles by multiplex polymerase chain reaction (PCR) method from colistin-resistant $E$. coli, which was originated from the broiler meat supply chain in Bogor, West Java, Indonesia.

\section{Materials and Methods}

\section{Ethical approval}

This study did not use live animals, so ethical approval was not needed.

\section{Study period and location}

The study was conducted from August 2019 to February 2020. Culture and re-identification, phylogenetic group determination, and detection of virulence genes were carried out at the National Veterinary Drug Assay Laboratory (NVDAL), Directorate General of Livestock and Animal Health Services, Ministry of Agriculture of the Republic of Indonesia.

\section{Samples}

The colistin-resistant $E$. coli used in this study was derived from 58 archive isolates isolated in 2017 from the broiler meat supply chain in Bogor, West Java, Indonesia [11]. The samples originated from the cloacal swab, litter, drinking water, inside plucker swab, fresh meat at small scale poultry slaughterhouses (SSPS), and traditional markets (TM). All of these isolates were tested for sensitivity to colistin sulfate using the agar dilution method.

\section{Culture and identification}

All isolates were cultured and re-identified. These isolates were inoculated on the heart infusion broth (HIB) media (Difco, USA) and incubated at $37^{\circ} \mathrm{C}$ for $18-24 \mathrm{~h}$. These bacteria were cultured on MacConkey agar (Oxoid, UK) and eosin methylene blue agar (Oxoid, UK) and incubated at $37^{\circ} \mathrm{C}$ for 18-24 h. The E. coli suspected colony inoculated on heart infusion agar (HIA) media (Difco, USA) for $18-24 \mathrm{~h}$ at $37^{\circ} \mathrm{C}$, then the Gram staining and biochemical testing were carried out. Biochemical tests used were the IMViC test and triple sugar iron agar (Oxoid, UK). The IMViC test consists of sulfite indole motility (Oxoid, UK), methyl red-Voges-Proskauer (MR-VP) (Merck, Germany), and Simmons citrate agar (Oxoid, UK). Isolates confirmed by E. coli showed IMViC results: Indole (+), MR (+), VP (-), and Citrate (-) [12]. E. coli ATCC 25922 was used as a positive control. All archive $E$. coli isolates were reconfirmed their sensitivity to colistin sulfate antibiotics using the agar dilution method $[13,14]$.

\section{Genomic extraction of $E$. coli DNA}

The E. coli isolates were enriched with HIB for $18-24 \mathrm{~h}$ at $37^{\circ} \mathrm{C}$. The isolates then inoculated on HIA for $18-24 \mathrm{~h}$ at $37^{\circ} \mathrm{C}$. E. coli colonies on HIA were further extracted for phylogenetic group determination, as well as the detection of virulence genes. DNA extraction using the boiling method with BufferPrepMan ${ }^{\circledR}$ Ultra Sample Preparation Reagent (Applied Biosystems, USA).

\section{Phylogenetic group determination with PCR}

The determination of $E$. coli was carried out according to the method of Clermont et al. [15] to the A, B1, B2, or D phylogenetic groups. This method is based on the analysis of the presence of the chuA and the yjaA genes also DNA fragments (TSPE4.C2) by the triplex PCR method. Primer sequences, gene targets, amplicon lengths, and annealing temperatures are shown in Table-1 [15]. DNA amplification using the HotStarTaq ${ }^{\circledR}$ Master Mix Kit (Qiagen, Germany) with a total PCR reagent volume of $25 \mu \mathrm{L}$ consisting of $12.5 \mu \mathrm{L}$ HotStarTaq ${ }^{\circledR}$ Master Mix, $1 \mu \mathrm{L}$ of each primer $(20 \mu \mathrm{M}), 5.5 \mu \mathrm{L} \mathrm{dH}_{2} \mathrm{O}$, and $5 \mu \mathrm{L}$ DNA templates. The PCR process using Proflex ${ }^{\text {TM }} 3 \times 32$-well PCR System (Thermo Fisher Scientific, USA). The PCR was carried out with a $95^{\circ} \mathrm{C}$ predenaturation cycle for $15 \mathrm{~min}$, followed by 30 cycles consisting of denaturation of $94^{\circ} \mathrm{C}$ for $1 \mathrm{~min}$, annealing $54^{\circ} \mathrm{C}$ for $1 \mathrm{~min}$, and extension at $72^{\circ} \mathrm{C}$ for $1 \mathrm{~min}$. The final extension was carried out at $72^{\circ} \mathrm{C}$ for $1 \mathrm{~min}$. PCR products were visualized using a $1.5 \%$ agarose gel with SYBR Safe DNA Gel Stain alongside a $100 \mathrm{bp}$ DNA Ladder (Thermo Fisher Scientific, USA). E. coli ATCC 25922 was used as a positive control of the chuA, yjaA genes, and DNA fragments (TSPE4.C2) [16] together with E. coli APEC strain O2 [17] obtained from the NVDAL.

\section{Detection of virulence genes by PCR}

The detection of virulence genes was carried out according to the method of Johnson et al. [18] targeting iutA, $h l y F$, iss, iroN, and ompT genes. Primary sequences, gene targets, amplicons, and annealing temperatures are shown in Table-2 [18-21]. DNA amplification using the HotStarTaq ${ }^{\circledR}$ Master Mix Kit (Qiagen, Germany) with a total PCR reagent volume of $25 \mu \mathrm{L}$ consisting of $12.5 \mu \mathrm{L} \operatorname{HotStarTaq}^{\circledR}$ Master

Table-1: Primer sets for phylogenetic group determination of Escherichia coli.

\begin{tabular}{|c|c|c|c|c|c|}
\hline No. & Target gene (group) & Primer & $\begin{array}{c}\text { Annealing } \\
\text { temperature }\left({ }^{\circ} \mathrm{C}\right)\end{array}$ & $\begin{array}{l}\text { Amplicon } \\
\text { (bp) }\end{array}$ & References \\
\hline \multirow[t]{2}{*}{1} & \multirow{2}{*}{$\begin{array}{l}\text { chuA } \\
\text { (B2 or D) }\end{array}$} & (F) 5'- GACGAACCAACGGTCAGGAT-3' & \multirow[t]{2}{*}{54} & \multirow[t]{2}{*}{279} & \multirow[t]{4}{*}[15]{} \\
\hline & & (R) 5'- TGCCGCCAGTACCAAAGACA-3' & & & \\
\hline \multirow[t]{2}{*}{2} & \multirow{2}{*}{$\begin{array}{l}\text { yjaA } \\
(\mathrm{B} 2)\end{array}$} & (F) 5'- TGAAGTGTCAGGAGACGCTG-3' & \multirow[t]{2}{*}{54} & \multirow[t]{2}{*}{211} & \\
\hline & & (R) 5'- ATGGAGAATGCGTTCCTCAAC-3' & & & \\
\hline \multirow[t]{2}{*}{3} & \multirow{2}{*}{$\begin{array}{l}\text { TspE4C2 } \\
(\mathrm{B} 1 \text { or } \mathrm{A})\end{array}$} & (F) 5'- GAGTAATGTCGGGGCATTCA-3' & \multirow[t]{2}{*}{54} & \multirow[t]{2}{*}{152} & \\
\hline & & (R) 5'- CGCGCCAACAAAGTATTACG-3' & & & \\
\hline
\end{tabular}


Mix, $1 \mu \mathrm{L}$ of each primer $(20 \mu \mathrm{M}), 5.5 \mu \mathrm{L} \mathrm{dH}_{2} \mathrm{O}$, and $5 \mu \mathrm{L}$ DNA templates. The PCR process using Proflex $^{\mathrm{TM}} 3 \times 32$-well PCR System (Thermo Fisher Scientific, USA). The PCR process was carried out with a $95^{\circ} \mathrm{C}$ predenaturation cycle for $15 \mathrm{~min}$. The next process is 30 cycles consisting of denaturation of $94^{\circ} \mathrm{C}$ for $1 \mathrm{~min}$, annealing $63^{\circ} \mathrm{C}$ for $1 \mathrm{~min}$, and extension at $72^{\circ} \mathrm{C}$ for $1 \mathrm{~min}$, and the end of the amplification is followed by a final extension at $72^{\circ} \mathrm{C}$ for $1 \mathrm{~min}$. PCR products were visualized on a $1.5 \%$ agarose gel with SYBR Safe DNA Gel Stain and using 100 bp DNA Ladder (Thermo Fisher Scientific, USA). Positive control of the five APEC marker genes used E. coli $\mathrm{O} 2$ strain obtained from the NVDAL.

\section{Statistical analysis}

The distribution pattern of phylogenetic groups and virulence genes was compared with Fisher's exact test (two-sided) with a confidence value of $p<0.05$. This statistical test was performed with the SPSS statistical program version 2.3 (IBM Corp., NY, USA).

\section{Results}

The results of the re-identification of all 58 isolates of colistin-resistant $E$. coli archive showed that all isolates were confirmed to be E. coli. All of the isolates were resistant to colistin sulfate with a minimum inhibitory concentration value of more than
$2 \mu \mathrm{g} / \mu \mathrm{L}[13]$. Phylogenetic determination of isolates carried out by multiplex PCR (Figure-1) showed that $34.48 \%$ isolates belong to Group A (20/58), 34.48\% isolates were Group D), $17.24 \%$ were Group B1 $(10 / 58)$, and $13.79 \%$ belong to Group B2 (8/58) (Table-3). The combination of three genetic markers, namely, the chuA and yjaA genes, also the TSPE4. C2 fragment, can distinguish the $E$. coli phylogenetic groups. E. coli ATCC 25922 and APEC O2 strain were used as positive controls. Both of them showed bands from the three genetic markers.

The distribution patterns of phylogenetic groups and virulence genes in 58 isolates of colistin-resistant E. coli are shown in Table-4. The iutA gene was the most prevalent gene as it was detected in 21 isolates (36\%), followed by the $h l y F$ gene and the ompT gene, 12 isolates each $(21 \%)$, the iro $N$ gene, six isolates $(10 \%)$, and the iss gene, five isolates $(9 \%)$. The isolates included in the B2 phylogenetic group had more virulence genes, indicated by an average virulence gene (virulence score) of 2.2, followed by Group D with a score of 1.3, then Groups A and B1 with a score of 0.4 each, respectively. The iro $N, h l y F$, and ompT genes had a positive association with the phylogenetic Group B2 $(\mathrm{p} \leq 0.05)$.

The combination of five APEC virulence genes can be detected in isolates from the phylogenetic

Table-2: Primer sets for detection virulence gene profiles of Escherichia coli.

\begin{tabular}{|c|c|c|c|c|c|}
\hline No. & $\begin{array}{l}\text { Target } \\
\text { gene }\end{array}$ & Primer & $\begin{array}{c}\text { Annealing } \\
\text { temperature }\left({ }^{\circ} \mathrm{C}\right)\end{array}$ & $\begin{array}{l}\text { Amplicon } \\
\text { (bp) }\end{array}$ & References \\
\hline \multirow[t]{2}{*}{1} & iroN & (F) 5'- AATCCGGCAAAGAGACGAACCGCCT -3' & 63 & 553 & [19] \\
\hline & & (R) 5'- GTTCGGGCAACCCCTGCTITGACTTT -3' & & & \\
\hline \multirow[t]{2}{*}{2} & ompT & (F) 5'- TCATCCCGGAAGCCTCCCTCACTACTAT-3' & 63 & 496 & [19] \\
\hline & & (R) 5'- TAGCGTTTGCTGCACTGGCTTCTGATAC -3' & & & \\
\hline 3 & $h l y F$ & $\begin{array}{l}\text { (F) 5'- GGCCACAGTCGTTTAGGGTGCTTACC -3' } \\
\text { (R) 5'- GGCGGTTAGGCATTCCGATACTCAG -3' }\end{array}$ & 63 & 450 & {$[20]$} \\
\hline \multirow[t]{2}{*}{4} & iss & (F) 5'- CAGCAACCCGAACCACTTGATG-3' & 63 & 323 & [21] \\
\hline & & (R) 5'- AGCATTGCCAGAGCGGCAGAA- 3' & & & \\
\hline 5 & iutA & $\begin{array}{l}\text { (F) 5'- GGCTGGACATCATGGGAACTGG -3' } \\
\text { (R) 5'- CGTCGGGAACGGGTAGAATCG -3' }\end{array}$ & 63 & 302 & [18] \\
\hline
\end{tabular}

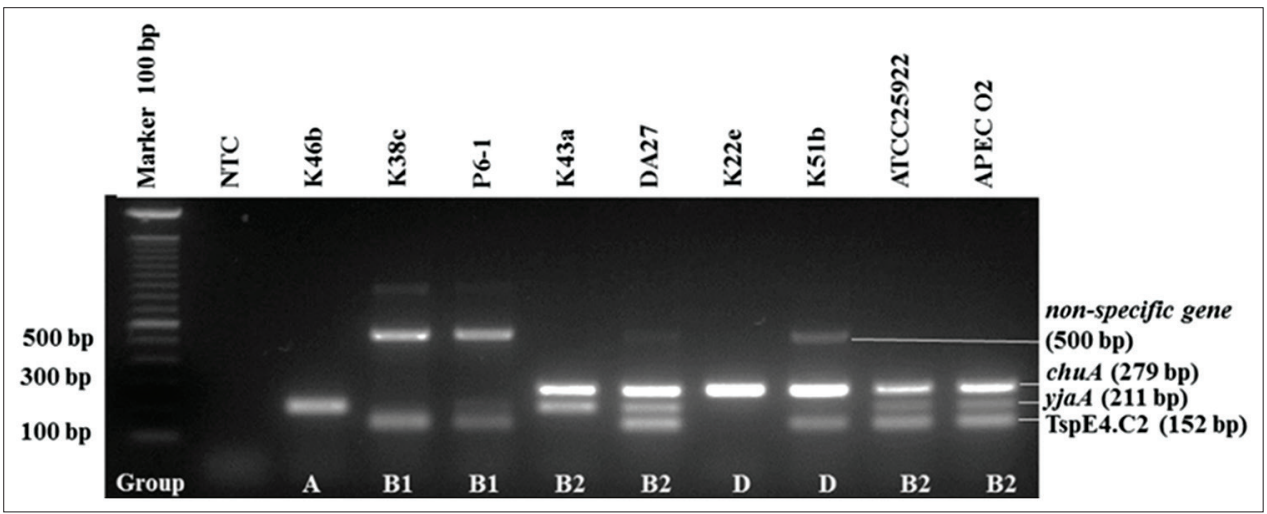

Figure-1: Triplex polymerase chain reaction phylogenetic group determination of Escherichia coli. NTC: Non-template control; isolate code: K46b (Group A); K38c and P6-1 (Group B1); K43a and DA27 (Group B2); K22e and K51b (Group D); positive control: E. coli ATCC 25922 and avian pathogenic E. coli O2 strain (Group B2). 
Group B2 (3.45\%), followed by Groups D and A $(1.72 \%)$. Thirty-six isolates did not express the five virulent genes (Table-5). The multiplex PCR profile of the five APEC genetic markers, namely, iro $N, h l y F$, iutA, ompT, and iss genes, is shown in Figure-2. The multiplex PCR results were able to show that the four isolates (K14c, K16d, K44d, and K45b) were APEC (Table-5). Positive control of E. coli APEC strain O2 showed positive results on these five APEC markers.

\section{Discussion}

This study provides the results of the determination of phylogenetic groups and virulence gene profiles of colistin-resistant $E$. coli originated from the broiler meat supply chain in Bogor, West Java, Indonesia. E. coli can be divided into pathogenic and commensal. Commensal E. coli was the majority strain and designated as a nonpathogenic strain. APEC, subpathotype of ExPEC, has the potential to cause infection in humans, vice versa. It is suggesting that these strains may lack host specificity [22]. APEC, UPEC, and NMEC have overlapping virulence encoding genes $[9,23]$. This APEC virulence gene can support the ExPEC virulence combination in survival, colonization, and infection. Therefore, APEC isolates have a potential zoonosis risk. Because of some virulence genes commonly found in mobile genetic elements like plasmid, there is a possibility of transfer of virulence genes to other commensal and pathogenic E. coli strains [18]. Apart from being a reservoir of antibiotic-resistant genes, APEC may act as a reservoir of virulence genes for ExPEC in humans [7].

The phylogenetic group determination was carried out by multiplex PCR with three genetic markers based on Clermont et al. [15] scheme. These markers were chosen because it was more practical and had results that were strongly correlated with other standard methods to distinguish $E$. coli phylogenetic groups $[15,24]$. As a positive control, E. coli ATCC 25922 and APEC O2 strain showed the positive

Table-3: Phylogenetic group determination of colistin-resistant Escherichia coli along broiler meat supply chain in Bogor.

\begin{tabular}{|c|c|c|c|c|c|c|c|c|c|c|}
\hline \multirow{2}{*}{$\begin{array}{l}\text { Phylo } \\
\text { group }\end{array}$} & \multicolumn{3}{|c|}{ Genetic marker } & \multicolumn{6}{|c|}{ Type of isolate source } & \multirow[t]{2}{*}{ Total (\%) } \\
\hline & chuA & yjaA & $\begin{array}{c}\text { TSPE4. } \\
\text { C2 }\end{array}$ & $\begin{array}{c}\text { Cloacal } \\
\text { swab }\end{array}$ & $\begin{array}{l}\text { Drinking } \\
\text { water }\end{array}$ & Litter & $\begin{array}{c}\text { Inside } \\
\text { plucker swab }\end{array}$ & $\begin{array}{l}\text { Fresh meat } \\
\text { (SSPS) }\end{array}$ & $\begin{array}{c}\text { Fresh } \\
\text { meat (TM) }\end{array}$ & \\
\hline$A$ & - & \pm & - & $9 / 31$ & $2 / 4$ & $1 / 4$ & $0 / 2$ & $3 / 7$ & $5 / 10$ & $\begin{array}{c}20 / 58 \\
(34.48)\end{array}$ \\
\hline $\mathrm{B} 1$ & - & \pm & + & $5 / 31$ & $2 / 4$ & $0 / 4$ & $1 / 2$ & $1 / 7$ & $1 / 10$ & $\begin{array}{c}10 / 58 \\
(17.24)\end{array}$ \\
\hline B2 & + & + & \pm & $5 / 31$ & $0 / 4$ & $1 / 4$ & $0 / 2$ & $0 / 7$ & $2 / 10$ & $\begin{array}{c}8 / 58 \\
(13.79)\end{array}$ \\
\hline $\mathrm{D}$ & + & - & \pm & $12 / 31$ & $0 / 4$ & $2 / 4$ & $1 / 2$ & $3 / 7$ & $2 / 10$ & $\begin{array}{c}20 / 58 \\
(34.48)\end{array}$ \\
\hline Total & & & & 31 & 4 & 4 & 2 & 7 & 10 & 58 \\
\hline
\end{tabular}

SPSS $=$ Small scale poultry slaughterhouse, $\mathrm{TM}=$ Traditional market

Table-4: Phylogenetic group and virulence gene profiles of 58 colistin-resistant Escherichia coli isolate.

\begin{tabular}{lcccccc}
\hline Group (n) & \multicolumn{5}{c}{ Prevalence n (\%) } \\
\cline { 2 - 6 } & iro & hly & iutA & ompt & iss & VS\# \\
\hline A (20) & $1(5)$ & $1(5)$ & $4(20)$ & $1(5)$ & $1(5)$ & 0.4 \\
B1 (10) & $1(10)$ & $1(10)$ & $0(0)$ & $1(10)$ & $1(10)$ & 0.4 \\
B2 (8) & $3(37)^{*}$ & $4(50)^{*}$ & $5(62)$ & $4(50)^{*}$ & $2(25)$ & $2.2^{\#}$ \\
D (20) & $1(5)$ & $6(30)$ & $12(60)$ & $6(30)$ & $1(5)$ & 1.3 \\
Total (58) & $6(10)$ & $12(21)$ & $21(36)$ & $12(21)$ & $5(9)$ & 1.0 \\
\hline
\end{tabular}

*The positive association between phylogenetic group and virulence genes $(p \leq 0.05)$. ${ }^{\vee V S}=$ Virulence score. A virulence score was calculated for each isolate as the sum of all virulence genes. $p$ value was determined using Fisher's exact test for comparisons among phylogenetic groups and virulence genes

Table-5: Combined profile of virulence genes and phylogenetic groups in 58 Escherichia coli isolates.

\begin{tabular}{|c|c|c|c|c|c|c|}
\hline \multirow{2}{*}{$\begin{array}{l}\text { Phylogroup } \\
\text { (n) }\end{array}$} & \multicolumn{5}{|c|}{ Combined profile of virulence genes $(\%)$} & \multirow{2}{*}{$\begin{array}{c}\text { Not } \\
\text { detected }\end{array}$} \\
\hline & $\begin{array}{c}\text { iroN, hlyF, iutA, } \\
\text { ompT, iss }\end{array}$ & $\begin{array}{c}\text { iroN, hlyF, ompt, } \\
\text { iss }\end{array}$ & $\begin{array}{l}\text { hlyF, iutA, } \\
\text { ompT }\end{array}$ & $\begin{array}{c}\text { iroN, } \\
\text { iutA }\end{array}$ & iutA & \\
\hline$A(20)$ & $1(1.72)$ & $0(0)$ & $0(0)$ & $0(0)$ & $3(5.17)$ & $16(27.59)$ \\
\hline $\mathrm{B} 1(10)$ & $0(0)$ & $1(1.72)$ & $0(0)$ & $0(0)$ & $0(0)$ & $9(15.52)$ \\
\hline B2 (8) & $2(3.45)$ & $0(0)$ & $1(1.72)$ & $1(1.72)$ & $0(0)$ & $3(5.17)$ \\
\hline $\mathrm{D}(20)$ & $1(1.72)$ & $0(0)$ & $6(10.34)$ & $0(0)$ & $6(10.34)$ & $8(13.79)$ \\
\hline Total (58) & $4(6.90)$ & $1(1.72)$ & $7(12.07)$ & $1(1.72)$ & $9(15.52)$ & $36(62.07)$ \\
\hline
\end{tabular}

Virulence genes: iroN, $h l y F$, iutA, ompT, and iss 


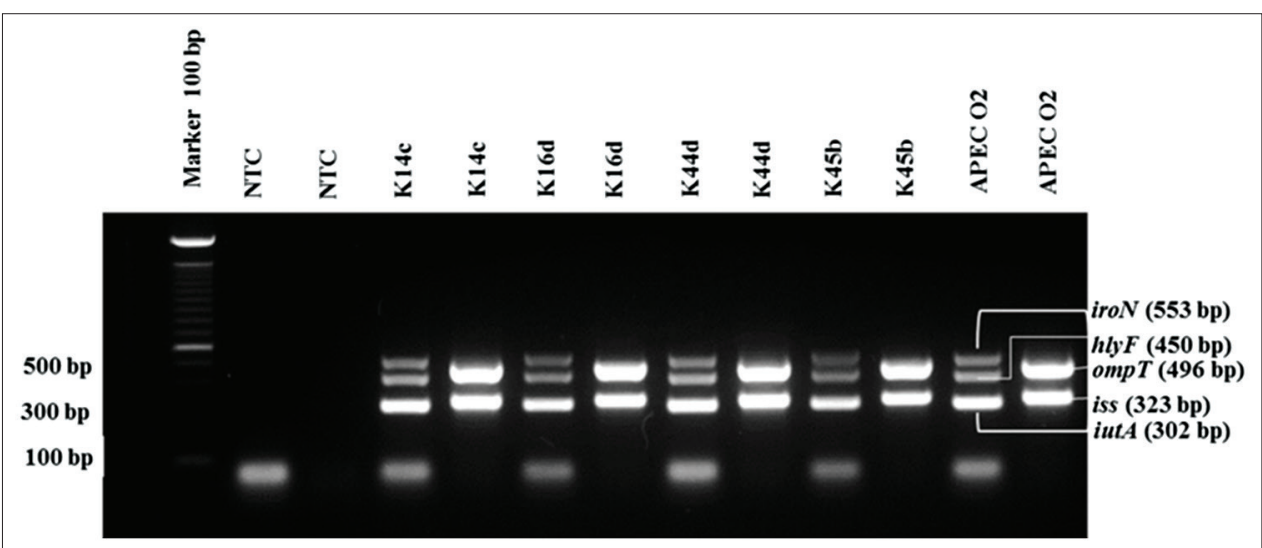

Figure-2: Multiplex polymerase chain reaction profile from five genetic markers (iroN, hly $F$, iutA, ompT, and iss) can detect avian pathogenic Escherichia coli (APEC) strains. Isolate code K14c, K16d, K44d, and K45b showed positive results of iroN, hlyF, iutA, ompT, and iss. NTC: Non-template control; positive control: E. coli APEC O2.

results of the three genetic markers, which indicated that the isolates belong to the B2 group (Figure-1). In PCR results, positive isolates of TspE4.C2 fragments (152 bp) are often, followed by the appearance of non-specific bands with an amplicon of $500 \mathrm{bp}$. This extra band is seen more clearly in some isolates which belong to the B1 group. These results are consistent with research conducted by Castillo et al. [25] that stated that sequencing from the $528 \mathrm{bp}$ extra band showed that there was $100 \%$ homology with lipase (acetyl-hydrolase) found in pathogenic strains of $E$. coli belonging to the $\mathrm{B} 1$ group. Therefore, this extra band could be used to differentiate pathogenic E. coli isolates and commensals included in the B1 group. In this study, out of the ten isolates belonged to the B1 group, four were commensal. The remaining six were pathogenic isolates that were characterized by the presence of extra bands in $500 \mathrm{bp}$. The analysis of the results of the determination of phylogenetic groups showed that the majority of isolates belong to Groups $\mathrm{A}$ and D, followed by Groups B1 and B2. According to Johnson et al. [18], ExPEC is mostly included in Groups B2 and D, while non-pathogenic E. coli tends to belong to the B1 group and the A group.

The identification of virulence gene profile was carried out by the multiplex PCR method with five plasmid genes as APEC markers (iss, iroN, ompT, iutA, and $h l y F$ genes) [18]. These five genes are similar to the virulence genes in ExPEC that infect humans. Therefore, the E. coli strain with the five genes in the plasmid can potentially be zoonotic [8]. Studies in several countries showed that most APEC strains belong to the B2 group and the D group [17,26,27], as well as ExPEC in the majority of humans, including in the B2 group and several D groups $[15,28]$. In this study, four APEC isolates were obtained (with code K14c, $\mathrm{K} 16 \mathrm{~d}, \mathrm{~K} 44 \mathrm{~d}$, and K45b) (Figure-2). All four isolates, along with positive control of the E. coli APEC O2 strain, showed positive PCR results on the five APEC marker genes. Of the four APEC isolates, two of them belong to the B2 group (K14c and K44d), and two of the other isolates belong to the D group (K16d) and the A group (K45b). The presence of A group that is commensal E. coli raises the suspicion that the commensal isolate has received all five APEC virulence genes from other E. coli. Several studies have stated that commensal $E$. coli can obtain virulence genes through horizontal gene transfer from pathogenic strains that cause intestinal or extraintestinal diseases in animals and humans $[4,29]$. The most prevalent virulence genes were iutA (36\%), followed by $h l y F$ and ompT (21\%), iroN (10\%), and iss (9\%). The iutA gene is a pathogenic gene that causes APEC [30,31]. The study conducted by Johnson et al. [19] stated that more than $80 \%$ of $E$. coli isolates possessing plasmid genes, namely, the iroN, the iutA, and the $h l y F$ genes, play a role in colibacillosis in poultry. Filho et al. [3] reported that $83 \%$ of the 994 APEC samples were positive for iro $N$ and $h l y F$ genes.

The isolates belonging to the B2 phylogenetic group had more virulence factor encoding genes, indicated by the highest virulence scores, followed by the $\mathrm{D}$ group, the A group, and the B1 group (Table-4). The iroN, $h l y F$, and ompT genes have a positive association with the phylogenetic group $\mathrm{B} 2(\mathrm{P} \leq 0.05)$. The $h l y F$ gene plays a role in the formation of outer membrane vesicles (OMVs) in E. coli bacteria and in the preparation of the hemolysin $\mathrm{F}$ protein that functions to lyse the host's red blood cells [32]. Several studies found that the ompT gene can break down the host antimicrobial peptides, namely, protamine and plasminogen from E. coli isolated from patients with UTI and APEC [33,34]. The iss gene (increased serum survival) is related to APEC's self-defense mechanism against the host's body's defense system [18].

The most prevalent APEC virulence gene in this study was iutA gene (36\%). The iutA as well as iroN virulence genes are very important for APEC and human ExPEC to maintain their life in the host body. Both of these genes encode siderophore. Siderophore is an iron-binding molecule, which binds the ferric ion in $E$. coli external environment. The iutA gene encodes the aerobactin siderophore receptor, while the iroN gene encodes salmochelin siderophore $[35,36]$. The 
iron itself is a vital component in bacterial biological processes, such as energy formation, oxygen transport, and DNA replication [37]. APEC and human ExPEC develop the mechanism of iron acquisition systems from their host body by producing siderophore. It is because of the low availability of iron in the extraintestinal site in the location where the infection occurs. Recent studies have shown that this system contributes to the virulence of APEC and human ExPEC in terms of attachment and invasion [38,39].

The combination of the APEC virulence genes can be detected in isolates from the phylogroup B2 $(3.45 \%)$, followed by Groups D and A (1.72\%). Isolates included in Groups A and B1 had a combination of APEC virulence factor coding genes (Table-5). Based on these results, there are presumptions that the isolate obtained the acquisition of virulence genes from other APEC isolates. According to Johnson et al. [19], the iroN, $h l y F$, iutA, ompT, and iss genes are found in the pAPEC-O2-ColV plasmid. This genetic information (virulence genes) can be transferred through horizontal gene transfer mechanisms by mobile plasmids [40]. The undetection of the five virulence genes in 36 isolates showed that the isolates were probably commensal or derived from other pathotypes to have different virulence factor combinations.

It is essential to determine phylogenetic groups and virulence gene profiles in colistin-resistant isolates from the broiler meat supply chain. Five genes studied in this research are APEC markers plasmid genes. These genes may cause colibacillosis in chickens, as well as create zoonotic potential and may act as a reservoir of virulence genes for human ExPEC can be propagated to human and other strains of $E$. coli, both commensal and pathogenic. Besides being useful in the characterization of pathogenic $E$. coli isolates, studies of the profile of virulence genes in $E$. coli are essential because they can be used as a basis for developing effective vaccines [41].

In this study, there was an isolate that originated from fresh meat in TM belongs to the B2 group and have two genes, namely, the iroN and the iutA genes, located in the plasmid and may act as human ExPEC reservoirs. One isolate belongs to the $\mathrm{B} 1$ commensal group originating from the cloacal swab. Still, it has four genes encoding the virulence APEC factor, so there is a suspicion that the isolate obtained the virulence gene acquisition from another APEC isolate. Several studies stated that genetic information, in this case, virulence genes, can be transferred through the mechanism of horizontal gene transfer by mobile genetic elements (plasmids, bacteriophages, and genomic islands). The evolution of $E$. coli strains is highly determined in the genomic region, and this mechanism $[5,40,42,43]$. The virulence APEC genes and the antibiotic-resistant genes are often on the same plasmid [44], so it potential to be transferred to other $E$. coli bacteria.

$E$. coli isolates with five virulence genes are at risk of causing zoonotic diseases in poultry workers, workers in SSPS, the sellers in TM, and consumers if they consume meat that is not processed correctly. These isolates have a zoonotic risk and also as a reservoir of ExPEC virulent genes in the environment. Healthy chickens can spread $E$. coli, which has virulence genes into the environment, through manures derived from farm waste that can contaminate agricultural fields and public waters $[5,45]$. The potential spread throughout the broiler meat supply chain must be minimized to produce a product that is safe for consumption. Good farming practices, especially the sanitation of the bedding and proper ventilation system, must be considered. Probiotics and vaccinations are needed to prevent colibacillosis on broiler farms. Hygiene and sanitation at the retail market, as well as proper carcass processing, can reduce the potency for the spread of zoonotic pathogenic $E$. coli and antibiotics resistant [46].

Further research is needed to prove the virulence of APEC isolates in the host. According to Filho et al. [3], subcutaneous inoculation of APEC isolates in embryos or day-old chicken (DOC) is the gold standard method for confirming the virulence of E. coli. E. coli isolates are proven to be pathogenic if the embryo dies or there are specific lesions, followed by death in the DOC. The mechanism of virulence genes transfer horizontally needs to be proven.

\section{Conclusion}

Pathogenic E. coli isolates from phylogroup B2 and $\mathrm{D}$ are found along the broiler meat supply chain obtain from Bogor, West Java. Virulence factor coding genes are also found in isolates from Groups A and B1 commonly owned by commensal $E$. coli. The B2 group isolates had a positive association with the virulence APEC marker genes contained in the plasmid (iroN, $h l y F$, and ompT). The virulence genes can potentially be transferred to other $E$. coli, both commensal and pathogenic. The isolate can contaminate carcass if the processing does not conform to proper procedures. It was found to be a potential danger from the spread of virulence genes by $E$. coli isolates obtained from the broiler meat supply chain in Bogor, West Java, Indonesia.

\section{Authors' Contributions}

IR designed the study and drafted the manuscript under the supervision of AI and IWTW. MFP collected samples and did colistin resistance susceptibility testing. IR performed the test and data analysis under the supervision of AI, IWTW, and II. All authors have read and approved the final manuscript.

\section{Acknowledgments}

We want to thank Mrs. Sri Mukartini, Chief of National Veterinary Drug Assay Laboratory (NVDAL) for permission and support, the staff of Bacteriology Laboratory, Biotechnology Laboratory, and Pharmaceutical and Premix Laboratory NVDALBogor, Indonesia, for technical support, and also the 
staffs of Division Department of Animal Disease and Veterinary Public Health, Faculty of Veterinary Medicine, IPB University-Bogor, Indonesia. We are also grateful to the Agency for Agricultural Extension and Human Resources Development (AAEHRD) Ministry of Agriculture of the Republic of Indonesia that has provided scholarship and research funds (Grant number: 751/KPTS/Kp.320/10/2018).

\section{Competing Interests} interests.

The authors declare that they have no competing

\section{Publisher's Note}

Veterinary World remains neutral with regard to jurisdictional claims in published institutional affiliation.

\section{References}

1. Kaper, J.B., Nataro, J.P. and Mobley, H.L.T. (2004) Pathogenic Escherichia coli. Nature, 2(2): 123-140.

2. Mellata, M. (2013) Human and avian extraintestinal pathogenic Escherichia coli: Infections, zoonotic risks, and antibiotic resistance trends. Foodborne Pathog. Dis., 10(11): 916-932.

3. Filho, H.C.K., Brito, K.C.T., Cavalli, L.S. and Brito, B.G. (2015) Avian pathogenic Escherichia coli (APEC)-an update on the control. In: Méndez-Vilas, A., editor. The Battle Against Microbial Pathogens: Basic Science, Technological Advances and Educational Programs. Formatex Research Center, Badajoz, Spain. p598-618.

4. Cunha, M.P.V., Saidenberg, A.B., Moreno, A.M., Ferreira, J.P., Vieira, M.A.M., Gomes, T.A.T. and Knöbl, T.K. (2017) Pandemic extra-intestinal pathogenic Escherichia coli (ExPEC) clonal group O6-B2-ST73 as a cause of avian colibacillosis in Brazil. PLoS One, 12(6): 1-11.

5. Sarowska, J., Futoma-Koloch, B., Jama-Kmiecik, A., FrejMadrzak, M., Ksiazczyk, M., Bugla-Ploskonska, G. and Choroszy-Krol, I. (2019) Virulence factors, prevalence and potential transmission of extraintestinal pathogenic Escherichia coli isolated from different sources: Recent reports. Gut. Pathog., 11(10): 1-16.

6. Johnson, T.J., Logue, C.M., Johnson, J.R., Kuskowski, M.A., Sherwood, J.S., Barnes, H.J., DebRoy, C., Wannemuehler, Y.M., Obata-Yasuoka, M., Spanjaard, L. and Nolan, L.K. (2012) Associations between multidrug resistance, plasmid content, and virulence potential among extraintestinal pathogenic and commensal Escherichia coli from humans and poultry. Foodborne Pathog. Dis., 9(1): 37-46.

7. Olsen, R.H., Christensen, H. and Bisgaard, M. (2012) Comparative genomics of multiple plasmids from APEC associated with clonal outbreaks demonstrates major similarities and identifies several potential vaccine-targets. Vet. Microbiol., 158(3-4): 384-393.

8. Manges, A.R. and Johnson, J.R. (2012) Food-borne origins of Escherichia coli causing extraintestinal infections. Clin. Infect. Dis., 55(5): 712-719.

9. Zhao, L., Gao, S., Huan, H., Xu, X., Zhu, X., Yang, W., Gao, Q. and Liu, X. (2009) Comparison of virulence factors and expression of specific genes between uropathogenic Escherichia coli and avian pathogenic E. coli in a murine urinary tract infection model and a chicken challenge model. Microbiology, 155(5): 1834-1644.

10. Tivendale, K.A., Logue, C.M., Kariyawasam, S., Jordan, D., Hussein, A., Li, G., Wannemuehler, Y. and Nolan, L.K. (2010) Avian-pathogenic Escherichia coli strains are similar to neonatal meningitis $E$. coli strains and are able to cause meningitis in the rat model of human disease. Infect.
Immun., 78(8): 3412-3419.

11. Palupi, M.F., Wibawan, I.W.T., Sudarnika, E., Maheswari, H. and Darusman, H.S. (2019) Prevalence of mcr-1 colistin resistance gene in Escherichia coli along broiler meat supply chain in Indonesia. Biotropia, 26(2): 1-15.

12. Indonesian National Standard. (2008) INS 2897: Methods of Microbial Contamination in Meat, 426 Eggs, and Milk, and their Processed Products. Standardization National Bureau, Jakarta.

13. European Committee on Antimicrobial Susceptibility Testing. (2020) Breakpoint Tables for Interpretation of MICs and Zone Diameters. Version 10.0. Available from: http://www.eucast.org. Retrieved on 10-01-2020.

14. Indrawati, A., Kurnia, R.S. and Mayasari, N.L.P. (2019). Detection of gene encoding resistance AMPC and MCR-1 in Escherichia coli causes avian colibacillosis in Sukabumi. J. Vet., 20(4): 495-503.

15. Clermont, O., Bonacorsi, S. and Bingen, E. (2000) Rapid and simple determination of the Escherichia coli phylogenetic group. Appl. Environ. Microbiol., 66(10): 4555-4558.

16. Osman, K.M., Kappell, A.D., El Hofy, F., Orabi, A., Mubarak, A.S., Dawoud, T.M., Moussa, I.M. and Hessain, A.M. (2018) Urinary tract infection attributed to Escherichia coli isolated from participants attending an unorganized gathering. Future Microbiol., 13(7): 745-756.

17. Ge, X.Z., Jiang, J., Pan, Z., Hu, L., Wang, S., Wang, H., Leung, F.C., Dai, J. and Fan, H. (2014) Comparative genomic analysis shows that avian pathogenic Escherichia coli isolate IMT5155 (O2:K1: H5;ST Complex 95, ST140) shares close relationship with ST95 APEC O1: K1 and human ExPEC O18: K1 strains. PLoS One, 9(11): e112048.

18. Johnson, T.J., Wannemuehler, Y., Doetkott, C., Johnson, S.J., Rosenberger, S.C. and Nolan, L.K. (2008) Identification of minimal predictors of avian pathogenic Escherichia coli virulence for use as a rapid diagnostic tool. J. Clin. Microbiol., 46(12): 3987-3996.

19. Johnson, T.J., Siek, K.E., Johnson, S.J. and Nolan, L.K. (2006) DNA sequence of a ColV plasmid and prevalence of selected plasmid-encoded virulence genes among avian Escherichia coli Strains. J. Bacteriol., 188(2): 745-758.

20. Morales, C., Lee, M.D., Hofacre, C. and Maurer, J.J. (2004). Detection of a novel virulence gene and a Salmonella virulence homologue among Escherichia coli isolated from broiler chickens. Foodborne Pathog. Dis., 1(3): 160-165.

21. Johnson, T.J., Wannemuehler, Y.M. and Nolan, L.K. (2008) Evolution of the Iss gene in Escherichia coli. Appl. Environ. Microbiol., 74(8): 2360-2369.

22. Krishnan, S., Chang, A.C., Hodges, J., Couraud, O.P., Romero, I.A., Weksler, B., Nicholson, B.A., Nolan, L.K. and Prasadarao, N.V. (2015) Serotype O18 avian pathogenic and neonatal meningitis Escherichia coli strains employ similar pathogenic strategies for the onset of meningitis. Virulence, 6(8): 777-786.

23. Breland, E.J., Eberly, A.R. and Hadjifrangiskou, M. (2017) An overview of two-component signal transduction systems implicated in extra-intestinal pathogenic E. coli infections. Front. Cell. Infect. Microbiol., 7(162): 1-14.

24. Gordon, D.M., Clermont, O., Tolleyand, H. and Denamur, E. (2008) Assigning Escherichia coli strains to phylogenetic groups: Multi-locus sequence typing versus the PCR triplex method. Environ. Microbiol., 10(10): 2484-2496.

25. Castillo, B.R.., Sosa, A.A.O. and Martinez, L.M. (2011) Detection of phylogenetic group B1 Escherichia coli by multiplex PCR: Description of a new amplification pattern. Enferm. Infecc. Microbiol. Clin., 29(10): 778-786.

26. Moulin-Schouleur, M., Répérant, M., Laurent, S., Brée, A., Grasteau, S.M., Germon, P., Rasschaert, D. and Schouler, C. (2007). Extraintestinal pathogenic Escherichia coli strains of avian and human origin: Link between phylogenetic relationships and common virulence patterns. J. Clin. Microbiol., 45(10): 3366-3376.

27. Cordoni, G., Woodward, M.J., Wu, H., Alanazi, M., 
Wallis, T. and La Ragione, R.M. (2016) Comparative genomics of European avian pathogenic E. coli (APEC). BMC Genomics, 17(960): 1-21.

28. Smith, J.L., Fratamico, P.M. and Gunther, N.W. (2007) Extraintestinal pathogenic Escherichia coli. Foodborne Pathog. Dis., 4(2): 134-163.

29. Johnson, J.R. and Russo, T.A. (2002) Extraintestinal pathogenic Escherichia coli: The other bad E coli. J. Lab. Clin. Med., 139(3): 155-162.

30. Vandekerchove, D., Vandemaele, F., Adriaensen, C., Zaleska, M., Hernalsteens, J.P., Baets, L.D., Butaye, P., Immerseel, F.V., Wattiau, P., Laevens, H., Mast, J., Goddeeris, B. and Pasmans, F. (2005) Virulence-associated traits in avian Escherichia coli: Comparison between isolates from colibacillosis-affected and clinically healthy layer flocks. Vet. Microbiol., 108(1-2): 75-87.

31. Hussein, A.H.M., Ghanem, I.A.I., Eid, A.A.M., Ali, M.A., Sherwood, J.S., Li, G., Nolan, L.K., Logue, C.M. (2013) Molecular and phenotypic characterization of Escherichia coli isolated from broiler chicken flocks in Egypt. Avian Dis., 57(3): 602-611.

32. Murase, K., Martin, P., Porcheron, G., Houle, S., Helloin, E., Pénary, M., Nougayrède, J., Dozois, C.M., Hayashi, T. and Oswald, E. (2016) HlyF produced by extraintestinal pathogenic Escherichia coli is a virulence factor that regulates outer membrane vesicle biogenesis. J. Infect. Dis., 213(5): 856-865.

33. Lundrigan, M.D. and Webb, R.M. (1992) Prevalence of ompT among Escherichia coli isolates of human origin. FEMS Microbiol. Lett., 97(1-2): 51-56.

34. Stumpe, S., Schmid, R., Stephens, D.L., Georgiou, G. and Bakker, E.P. (1998) Identification of OmpT as the protease that hydrolyzes the antimicrobial peptide protamine before it enters growing cells of Escherichia coli. J. Bacteriol. Res., 180(15): 4002-4006.

35. Feldmann, F., Sorsa, L.J., Hildinger, K. and Schubert, S. (2007) The salmochelin siderophore receptor iroN contributes to invasion of urothelial cells by extraintestinal pathogenic Escherichia coli in vitro. Infect. Immun., 75(6): 3183-3187.

36. Searle, L.J., Méric, G., Porcelli, I., Sheppard, S.K. and Lucchini, S. (2015) Variation in siderophore biosynthetic gene distribution and production across environmental and faecal populations of Escherichia coli. PLoS One, 10(3):
$1-14$.

37. Skaar, O.P. (2010) The battle for iron between bacterial pathogens and their vertebrate hosts. PLoS Pathog., 6(8): $1-4$.

38. Russo, T.A., Carlino, U.B. and Johnson, J.R. (2001) Identification of a new iron-regulated virulence gene, ireA, in an extraintestinal pathogenic isolate of Escherichia coli. Infect. Immun., 69(10): 6209-6216.

39. Russo, T.A., McFadden C.D., Carlino-MacDonald, U.B., Beanan, J.M, Barnard, T.J. and Johnson, J.R. (2002) IroN functions as a siderophore receptor and is a urovirulence factor in an extraintestinal pathogenic isolate of Escherichia coli. Infect. Immun., 70(12): 7156-7160.

40. Messerer, M., Fischer, W. and Schubert, S. (2017) Investigation of horizontal gene transfer of pathogenicity islands in Escherichia coli using next-generation sequencing. PLoS One, 12(7): 1-17.

41. Mbanga, J. and Nyararai, Y.O. (2015) Virulence gene profiles of avian pathogenic Escherichia coli isolated from chickens with colibacillosis in Bulawayo, Zimbabwe. Onderstepoort J. Vet. Res., 82(1): e1-e8.

42. Diard, M. and Hardt, W.D. (2017). Evolution of bacterial virulence. FEMS Microbiol. Rev., 41(5): 679-697.

43. Javadi, M., Bouzari, S. and Oloomi, M. (2017) Horizontal gene transfer and the diversity of Escherichia coli in: Samie, A., editor. Recent Advances Physiology, Pathogenesis and Biotechnological Applications, Chapter 16. London: IntechOpen: 317-331.

44. Ku, N.S., Lee, S.H., Lim, Y.S., Choi, H., Ahn, J.Y., Jeong, S.J., Shin, S.J., Choi, J.Y., Choi, Y.W., Yeom, J.S., Yong, D., Song, Y.G. and Kim, J.M. (2019) In vivo efficacy of combination of colistin with fosfomycin or minocycline in a mouse model of multidrug-resistant Acinetobacter baumannii pneumonia. Nature, 9(1): 1-7.

45. Hayashi, W., Tanaka, H., Taniguchi, Y., Limura, M., Soga, E., Kubo, R., Matsuo, N., Kawamura, K., Arakawa, Y., Nagano, Y. and Nagano, N. (2019) Acquisition of $m c r-1$ and cocarriage of virulence genes in avian pathogenic Escherichia coli isolates from municipal wastewater influents in Japan. Appl. Environ. Microbiol. 85(22): e01661-e01719.

46. Velhner, M., Suvajdžić, L., Todorović, D., Milanov, D. and Kozoderović, G. (2018) Avian pathogenic Escherichia coli: Diagnosis, virulence and prevention. Vet. Arh., 11(2): 21-31. 